KS. GINTER DZIERŻON

Uniwersytet Kardynała Stefana Wyszyńskiego w Warszawie

\title{
ZASADY FUNKCJONOWANIA AKTU PRZEŁOŻONEGO WYMAGAJĄCEGO WSPÓŁUDZIAŁU KONSULTACYJNEGO POJEDYNCZYCH OSÓB (KAN. 127 § KPK)
}

Treść: Wstęp. - 1. Założenia generalne. - 2. Przełożony. - 3. Unieważaniający charakter dyspozycji zawartej w kan. 127 § KPK. - 3.1. Konieczność uzyskania zgody (kan. 127 § 2, n. 1 KPK). - 3.2. Konieczność zasięgnięcia rady (kan. 127 § 2, n. 2 KPK). -4. Dyspensowanie. - Zakończenie.

\section{Wstęp}

W tytule VII Księgi I Kodeksu Prawa Kanonicznego poświęconego kwestii aktów prawnych (kan. 124-128 KPK), znalazła się dyspozycja dotycząca aktów podejmowanych przez przełożonego kościelnego wymagających współudziału pojedynczych osób. W kan. 127 § KPK bowiem prawodawca postanowił:

„Gdy ustawa postanawia, że przełożony do podjęcia pewnych aktów potrzebuje zgody lub rady niektórych pojedynczych osób wtedy:

1. jeśli wymagana jest zgoda, akt przełożonego jest nieważny bez zwrócenia się o wyrażenie zgody przez te osoby albo podjęty wbrew ich zdaniu lub któregoś z nich;

2. jeżeli jest wymagana rada nieważny jest akt przełożonego bez wysłuchania zdania tych osób. Wprawdzie przełożony nie ma żadnego obowiązku pójść za ich zdaniem, chociażby było zgodne, jednakże bez przeważającego powodu - przez siebie ocenionego - nie powinien odstępować od wyrażonego przez nich zadania, zwłaszcza gdy jest zgodne”.

Zapis tego kanonu stanowić będzie przedmiot uwagi w niniejszym opracowaniu. 


\section{Założenia generalne}

Dyspozycje zawarte w kan. 127 § 2 KPK różnią się od tych, które zostały skodyfikowane w paragrafie pierwszym tej regulacji. W kanonicznym porządku prawnym bowiem przewidziano możliwość podejmowania działań przez przełożonego nie tylko po uzyskaniu zgody, bądź zasięgnięciu rady kolegium lub zespołu osób, ale także po uzyskaniu zgody lub zasięgnięciu rady pojedynczych osób. Takie rozwiązanie występuje m. in. w kan. 524 KPK, zgodnie z którym biskup powinien powierzyć urząd proboszcza osobie do tego zdatnej po zasięgnięciu opinii dziekana, niektórych prezbiterów oraz wiernych świeckich ${ }^{1}$. Trzeba dodać, iż w przytoczonym kanonie idzie o osoby w znaczeniu indywiduum $^{2}$; nie idzie natomiast o osoby, które tworzą grupę konsultacyjną, W sensie kolegium lub zespołu osób, o których traktuje kan. 127 § 1 $\mathrm{KPK}^{3}$. Należy też dodać, że przełożony z osobą konsultowaną nie jest związany węzłem jedności, lecz jest podmiotem odrębnym od niej.

\section{Przełożony}

Akt o którym traktuje kan. $127 \S 2 \mathrm{KPK}$, jest aktem podejmowanym przez przełożonego. Przełożonym w kanonicznym porządku prawnym jest osoba zajmująca pozycję zwierzchnią względem innych osób ${ }^{5}$. W doktrynie nie ma wątpliwości co do tego, iż pod pojęcie ,przełożony” podpadają, takie autorytety, jak: ordynariusze (kan.

${ }^{1}$ Por. M. Thèriault, Comento al can. 127 CIC, w: Comentario exegético al Código de Derecho Canónico, red. A. Marzoa, J. Miras, R. Rodríguez - Ocaña, t. 1, Pamplona 1996, s. 833.

${ }^{2}$ Por. F. Aznar, Comento al can. 127 CIC, w: Código de Derecho Canónico. Edición bilingüe comentada, red. L De Echeveria, Madrd 1985, s. 103.

3 M. ThÈriault, Comento al can. 127 CIC, dz. cyt., s. 833: „El $§ 2$ si refiere al consentimiento o al consejo solicitado a individuos que no forman un grupo consultivo".

4 Por. J. García Martín, Le norme generali del Codex Iuris Canonici, Roma 1999, s. 438: „É ovvio che il Superiore non forma alcuna unitá con un'altra persona singola [...], ma rimane un soggetto distinto".

5 Por. U. RHode, Mitwirkugsrechte kirchlicher Autoritäten im Codex Iuris Canonici, St. Ottilien 2001, s. 166: „Der Ausdruck »Superior« bezeichnet eine Person, die andere gegenüber eine übergeordnete Stellung einnimmt". 
$134 \S 1$ KPK), prałaci personalni (kan. $295 \mathrm{KPK}$ ) oraz przełożeni Instytutów Życia Konsekrowanego oraz Stowarzyszeń Życia Apostolskiego ${ }^{6}$. Według kanonistów, zakresowo termin o którym mowa wykracza jednak poza autorytety wyliczone w kan. $134 \S 1 \mathrm{KPK}$; przełożonymi bowiem są też przełożeni Instytutów Świeckich oraz przełożone Żeńskich Instytutów Zakonnych, nie wymienione w kanonie ${ }^{7}$.

\section{Unieważaniający charakter dyspozycji zawartej w kan. 127 § 2 KPK}

Podobnie jak w paragrafie pierwszym kan. $127 \S 2$ KPK posiada charakter ustawy unieważniający. Podjęta bowiem przez przełożonego decyzja staje się nieważna, gdy nie uzyska on wymaganej prawem zgody, bądź też nie zasięgnie rady pojedynczych osób. Mechanizm funkcjonowania tej regulacji polega na tym, że w przypadku gdy przełożony nie skonsultuje zgodnie z prawem zamierzonej decyzji, podejmując ją autonomicznie, to nieważność jego działania wyniknie z faktu, iż zostanie on na mocy prawa uniezdolniony do podjęcia zamierzonego aktu. Innymi słowy, podjęty przez przełożonego akt będzie nieważny. Uniezdalniający charakter dyspozycji kan. 127 § 2 KPK doktryna wywodzi z normatywnego terminu ,indigere"

W tym kontekście trafnie zauważył H. Pree, że powzięte działanie byłoby nieważne niezależnie od tego, czy autorytet, o którym traktuje kan. $127 \S 2$ KPK wiedziałby, czy też nie wiedziałby, że do podjęcia tego typu aktu konieczny jest współudział osób trzecich ${ }^{9}$. W tej sytuacji bowiem znajduje aplikację zasada skodyfikowana w kan. $15 \S 1$

${ }^{6}$ Por. H. PreE, Allgemeine Normen, w: Münsterischer Kommentar zum Codex Iuris Canonici, red. K. Lüdicke, t. 1, Essen 1985, ad. 127, n. 2.

${ }^{7}$ Por. P. IvANDIĆ, Die verbindlich vorgeschriebenen Konsultationsorgane des Diözesanbischofs im universalen Recht der Lateinischen Kirche und deren Verwirklichung in den partikularnormen der Diözese Eisenstadt, Roma 2011, s. 18.

${ }^{8}$ H. Pree, Allgemeine Normen, dz. cyt., ad. 1127, n. 11.

9 Tamże. „Die Rechtsfolge der Nichtigkeit tritt auch dann ein, wenn sich der Obere (sei es schuldhaft oder auch nicht) in Unkenntnis oder Irrtum darüber befindet". 
KPK, zgodnie z którą ,.Ignorancja lub błąd dotyczące ustaw unieważniających lub uniezdalniających nie przeszkadzają ich skutkom"10.

Kontynuując wykładnię kan. 127 § 2 KPK należy też zauważyć, że w kanonie tym prawodawca nie odniósł się do kwestii zwołania pojedynczych osób. a także do sposobu uzyskania zgody lub rady. Oznacza to zatem, iż szczegółowe ustalenia $\mathrm{w}$ tej sprawie pozostają $\mathrm{w}$ gestii przełożonego $^{11}$.

\subsection{Konieczność uzyskania zgody (kan. 127 § 2, n. 1 KPK)}

Jak już zasygnalizowano, ustawodawca do podjęcia pewnej kategorii aktów prawnych wymaga uzyskania od przełożonego zgody pewnych osób. Z zapisu kan. $127 \S 2$, n. 1 KPK wynika, iż do ważności podejmowanej decyzji potrzebuje on zgody wszystkich osób. Analizując ten wątek V. De Paolis i A. D’Auria podkreślili, że w przywołanej hipotezie nie wystarcza zgoda większości ${ }^{12}$. Jeszcze precyzyjniej odniósł się do tej kwestii G. Ghirlanda stwierdzając, że w tym wypadku zgodę powinien on uzyskać od wszystkich osób, które są do tego uprawnione ${ }^{13}$. Jeżeli zatem przełożony w swym postępowaniu pominąłby jedną osobę, to w takiej sytuacji, pomimo uzyskania zgody od innych konsultowanych, podjęte przez niego działanie byłoby nieważne ${ }^{14}$.

${ }^{10}$ Szerzej na temat tej zasady zob. G. DzIERżon, Ignorancja i błąd a skuteczność ustaw unieważniającyh oraz uniezdalniaąacych w kanonicznym porządku prawnym (kan. $15 \oint$ $1 \mathrm{KPK}$ ), w: W kręgu nowożytnej i najnowszej historii ustroju Polski, Księga dedykowana Profesorowi Marianowi Kallasowi, red. S. Godek, D. Makieła, M. Wilczek-Karczewska, Warszawa 2010, s. 733-740.

${ }^{11}$ J. García Martín, Le norme generali, dz. cyt., s. 441.

${ }^{12}$ Por. V. De Paolis, A. D'Auria, Le norme generali di Diritto Canonico. Commento al Codice di Diritto Canonico, Roma 2008, s. 380: ,Se si esige il consenso, è necessario, per la validità dell'atto, che esso venga ottenuto da tutti e singoli'.

${ }^{13}$ Por. G. GhIrLanda, Atti giuridici e corresponsalbilità ecclesiale, w: L'atto giuridico nel diritto canonico, Città del Vaticano 2002, s. 306; J. ArRIETA, L'attività consultiva nell'amministrazione ecclesiastica di governo, w: Discrezionalità e discernimento nel governo della Chiesa, red. J. Arrieta, Venezia 2008, s. 151.

${ }^{14}$ H. PreE, Allgemeine Normen, dz. cyt., s. 374. 
Zdaniem kanonistów, sposób wyrażenia zgody uzależniony jest od uwarunkowań w których znajduje się przełożony. Do niego bowiem należy wybór formy najbardziej odpowiedniej ${ }^{15}$. W doktrynie nie wyklucza się też innej możliwości, jaką jest głosowanie w sprawie ${ }^{16}$. W tym wypadku jednak wymaga się głosowania jednomyślnego za zamierzeniem przełożonego. Jeśli więc zamierzonemu działaniu sprzeciwiałyby się w głosowaniu wszystkie osoby lub też któraś z nich, to wówczas akt podejmowany przez autorytet o którym traktuje kan. 127 $\S 2$, n. 1 KPK byłby nieważny. Podobne następstwa miałyby miejsce w wypadku, gdy jedna z osób konsultowanych nie zajęłaby stanowiska $\mathrm{W}$ zamierzonym przedsięwzięciu przełożonego ${ }^{17}$.

\subsection{Konieczność zasięgnięcia rady (kan. 127 § 2, n. 2 KPK)}

W analizowanym kan. $127 \S 2$ KPK występuje także druga hipoteza związana z koniecznością zasięgnięcia rady przez przełożonego kościelnego przy podejmowaniu pewnych decyzji określonych prawem.

W tym przypadku autorytet, o którym mowa w kan. $127 \S 2$ KPK, powinien wysłuchać zdania wszystkich osób prawnie zobligowanych do wyrażenia opinii ${ }^{18}$. Jeśli więc przełożony pominąłby chociażby jedną osobę, wtedy podjęte przez niego działanie byłoby nieważne ${ }^{19}$; nieważność powoduje także realna niemożliwość wyrażenia opinii przez konsultowanego ${ }^{20}$.W myśl doktryny, tak radykalne następstwa prawne

${ }^{15}$ G. GhiRlanda, Atti giuridici, dz. cyt., s. 306.

${ }^{16}$ Tamże.

${ }^{17}$ H. Pree, Allgemeine Normen, dz. cyt., ad. 1127, n.10; P. Ivandić, Die verbindlich vorgeschriebenen Konsultationsorgane, dz. cyt., s. 26.

${ }^{18}$ G. Ghirlanda, Atti giuridici, dz. cyt., s. 306; J. Arrieta, L'attività consultiva, dz. cyt., s. 151.

${ }^{19}$ Por. W. Aymans, K. Mörsdorf, Kanonisches Recht, t. 1, Padeborn - München - Wien - Zürich 1991, s. 374; P. Ivandí, Die verbindlich vorgeschriebenen Konsultationsorgane, dz. cyt., s. 27: „Besitzen Einzelnpersonen ein Anhörungsrecht, so muss der Obere jede einzelne dieser Personen hören. Würde er eine dieser Personen in ihren Recht übergehen, so hätte dies die Ungültigkeit seines Handels zur Folge”.

${ }^{20}$ P. Ivandić, Die verbindlich vorgeschriebenen Konsultationsorgane, dz. cyt., s. 29. 
nie powstają natomiast w sytuacji blokowania zamierzenia przez jedną lub kilka osób, poprzez niewyrażenie opinii ${ }^{21}$.

Z treści kan. 127 § 2, n. 2 KPK wynika, że przełożony w podejmowaniu decyzji finalnej nie jest bezwzględnie związany zdaniem poszczególnych osób ${ }^{22}$. Zasada o której mowa znajduje umocowanie w drugim zdaniu interpretowanej regulacji, w którym stwierdzono: „Wprawdzie przełożony nie ma żadnego obowiązku pójść za ich zdaniem, chociażby było zgodne, jednakże bez przeważającego powodu - przez siebie ocenionego - nie powinien odstępować od wyrażonego przez nich zadania, zwłaszcza gdy jest zgodne". Tego typu rozwiązanie wynika nie tyle $\mathrm{z}$ racji prawnych, ale przede wszystkim z racji eklezjologicznych, związanych z koncepcją Kościoła pojmowanego jako „communio” W tak pojętej wspólnocie bowiem występuje fenomen współodpowiedzialności za nią ${ }^{23}$. Dlatego też - jak stwierdził G. Girlanda - jest wolą prawodawcy, aby przełożony nie odstępował od zdania wyrażonego przez konsultantów, zwłaszcza wtedy gdy jest ono zgodne, gdyż Duch św. w Kościele działa nie tylko w osobie przełożonego, ale także przez wszystkich wiernych Kościoła ${ }^{24}$.

Przytoczony zapis ma charakter praktyczny i roztropnościowy ${ }^{25}$. Według H. Pree'a, przełożony nie powinien odstępować od opinii wyrażonej przez konsultantów, zwłaszcza wtedy, gdy nie osiągnął ugrun-

${ }^{21}$ Tamże, s. 27: „Im Unterschied zum geforderten consensus wird das Handeln des Oberen nicht schon dadurch blockiert, da $\beta$ er eine oder andere sich, obwohl gefragt, eine Meinugsäußerung enthält".

${ }^{22}$ V. De Paolis, A. D’Auria, Le norme generali, dz. cyt., s. 380; F. Aznar, Comento al can. 127 CIC, dz. cyt., s. 103.

${ }^{23}$ Szerzej na ten temat zob. P. Moneta, La libertà del fedele tra responsabilità ed esigenze di communione, w: I diritti fondamentali del fedele, Città del Vaticano 2004, s. 209-217.

${ }^{24}$ G. Ghirlanda, Atti giuridici, dz. cyt., s. 310: „[...] si comprende il senso della recomandazione contenuta nel c. $127 \S 2,2$, che specialmente nel caso di parere concorde di coloro che debbono darglielo, il Superiore, senza una ragione prevalente, da lui guidicata, non si discosti da esso. Infatti lo Spirito non agisce solo nel Superiore che deve prendere la decisione, ma in tutti coloro che la Chiesa stessa gli mette vicino, perché lo aiutino a prendere la decisione migliore per il bene della Chiesa, fine per conseguire il quale é data al Superiore la potestà".

${ }^{25}$ F. Aznar, Comento al can. 127 CIC, dz. cyt., s. 103. 
towanego stanowiska co do zaistniałej sytuacji, nie znajdując przekonujących argumentów za odrębnym stanowiskiem ${ }^{26}$. Jak podkreślił R. Sobański, zdanie poszczególnych osób nie jest wprawdzie wiążące, to jednak powinno być ono być brane pod uwagę z powagą i respektem $^{27}$. Należy dodać, iż pomimo tak ujętego normatywnie zalecenia, przełożony w podejmowaniu decyzji posiada autonomię; powinien on działać, zgodnie z własnym sumieniem i odpowiedzialnością, gdyż taka jest natura aktu prawnego, który podejmuje $\mathrm{e}^{28}$.

\section{Dyspensowanie}

Jak już wiadomo, dyspozycje zawarte w kan. $127 \S 2$ KPK posiadają charakter ustawy unieważniającej. Wobec takich ustaleń należałoby jeszcze zapytać o możliwość dyspensowania od ujętych w nim wymogów? Poruszając ten problem H. Pree skonstatował, iż wymagania te są mniej radykalne w odniesieniu do Stolicy Apostolskiej. Ona bowiem mogłaby dyspensować od warunków, które są pochodzenia czysto kościelnego ${ }^{29}$. Takiej decyzji natomiast nie mógłby podjąć biskup diecezjalny. Na mocy kan. 87 KPK posiada ona wprawdzie władzę dyspensowania od dyscyplinarnych powszechnych wydanych przez Stolicę Apostolską; nie ma on jednak władzy dyspensowania od elementu konstytutywnego zdolności przełożonego do podjęcia aktu prawnego (kan. $86 \mathrm{KPK})^{30}$.

${ }^{26}$ H. Pree, Allgemeine Normen, dz. cyt., ad. 1127, n.15: „Der Obere soll jedoch vom Votum der Ratgeber, besonders wenn einmütig gegeben wurde, nicht abweichen, wenn er nicht nach seinem Ermessen glaubt, überwiegende Gründe für seine abweichende Überzeugung zu besitzen".

${ }^{27}$ Por. R. Sobański, Komentarz do kan. 127 KPK, w: J. Krukowski, R. Sobański, Komentarz do Kodeksu Prawa Kanonicznego, t. 1, Poznań 2003, s. 210.

${ }^{28}$ Por. L. Chiappetta, $l l$ Codice di Diritto Canonico. Commento giuridco - pastorale, t. 1, Roma 1996, s. 196.

${ }^{29}$ H. PreE, Allgemeine Normen, dz. cyt., ad. 1127, n.11.

${ }^{30}$ L. Chiappetta, $l l$ Codice, dz. cyt., s. 197: „Il can. 87 riconosce al Vescovo diocesano la facoltà di dispensare delle leggi disciplinari della Chiesa anche di carattere universale, e a norma del can. 91 egli può esercitare tale facoltà sia verso gli altri, che verso se stesso. Aplicando tali canoni, può il Vescovo diocesano dispensarsi, in caso particolare, dall'obbligo di chiedere il consenso o il consiglio prescritto dalla legge? La 


\section{Zakończenie}

Hipoteza skodyfikowana w kan. 127 § 2 KPK zawiera zasady generalne związane z partycypacją innych osób w sprawowaniu władzy rządzenia przez przełożonych kościelnych poprzez pełnienie funkcji konsultacyjnych ${ }^{31}$. Według S. Berlingò, konieczność konsultacji jest wpisana w porządek konstytucyjny Kościoła ${ }^{32}$. Sakramentalność Kościoła, jego personalny charakter, a także natura diakonalna i kolegialna struktura, w przekonaniu J. Arriety, są pryncypiami charakterystycznymi funkcji publicznej Kościoła ${ }^{33}$. Według S. Berlingò, ochrzczeni z racji przyjętego sakramentu ontologicznie współuczestniczą we władzy rządzenia ${ }^{34}$. Prawda ta została m. in. wyrażona w Konstytucji Dogmatycznej o Kościele, w której stwierdzono „Ludzie świeccy, jak wszyscy wierzący chrześcijanie [...] niech im (pasterzom Kościoła G. D.) przedstawiają swoje potrzeby i życzenia z taką swobodą i ufnością, jak przystoi dzieciom Bożym i braciom w Chrystusie. [...] Powinno się to odbywać, jeśli zachodzi potrzeba, za pośrednictwem instytucji ustanowionych w tym celu przez Kościół [...]”' (KK 37).

Z aspektu eklezjologicznego konieczność konsultacji wynika w sposób szczególny z koncepcji Kościoła pojmowanego jako „communio”. $\mathrm{Z}$ tak rozumianej natury Kościoła bowiem wypływa potrzeba współodpowiedzialności za tę wspólnotę ${ }^{35}$. W tę wizję wpisany jest też fenomen dialektyki zachodzącej pomiędzy odpowiedzialnością osobistą przełożonego sprawującego władzę rządzenia oraz jego współodpowiedzialnością dzieloną z różnymi innymi podmiotami ${ }^{36}$.

Stąd też w obowiązującej kodyfikacji, oprócz regulacji wymagających w podejmowaniu decyzji przez przełożonego kościelnego współ-

risposta è negativa ai sensi del can. 86 , poiché si tratta di un elemento costitutivo della capacità del Superiore per poter porre in essere un atto giuridico".

${ }^{31}$ Por. S. Berlingò, "Consensus», "consilum» (cc. 127 C.I.C/934 C.C.E.O.) e esercizio della potestà ecclesiatica, Ius Canonicum 75 (1998), s. 89.

32 Tamże.

${ }^{33}$ J. ArrietA, L'attività consultiva, dz. cyt., s. 136.

${ }^{34} \mathrm{~S}$. BERLINGÒ, Il ministero pastorale, dz. cyt., s. 42-43.

${ }^{35}$ G. Ghirlanda, Atti giuridici, dz. cyt., s. 308.

${ }^{36}$ Tamże, s. 309-310. 
udziału organów partycypacji (kan. $127 \S 1 \mathrm{KPK}$ ), znalazły się także kanony obligujące przełożonych do konsultacji z pojedynczymi osobami. Odmienność wymogów ujętych w kan. $127 \S \S 1-2$ KPK wynika z waloru działań podejmowanych przez przełożonych kościelnych.

Zasady skodyfikowane w kan. 127 § 2 KPK znajdują aplikację w takich regulacjach kodeksowych, jak: 1) kan. $567 \S 1$ KPK w którym postanowiono, że ordynariusz miejsca nie powinien mianować kapelana laickiego instytutu zakonnego, bez konsultacji z przełożonym; 2) kan. $858 \S 2$ KPK w którym stwierdzono, iż ordynariusz miejsca, wysłuchawszy zdania proboszcza, może zezwolić lub nakazać aby chrzcielnica znajdowała się także w innym kościele lub kaplicy na terenie parafii; 3) kann. $1742 \S 1,1745,1750$ KPK nakazujące biskupowi diecezjalnemu konsultację przy usunięciu lub przenoszeniu proboszczów.

Akt o którym traktuje kan. $127 \S 2$ KPK jest aktem prawnym specyficznym. Osoby partycypujące bowiem współuczestniczą w procesie formacyjnym aktu wywierając wpływ na jego zawartość treściową; nie uczestniczą natomiast w fazie finalnej aktu związanej z podjęciem samej decyzji przez samego przełożonego ${ }^{37}$. Na marginesie należy dodać, iż podobne mechanizmy występują w aktach przełożonych dokonywanych przy współudziale organów partycypacji (kan. 127 § 1 KPK).

Z przeprowadzonej wykładni kan. 127 § 2 KPK wynika, iż w regulacji tej prawodawca zawarł dwie hipotezy, związane z koniecznością uzyskania zgody lub zasięgnięcia rady poszczególnych osób przez przełożonego kościelnego. Przy czym należy zauważyć, iż mechanizmy funkcjonowania tych hipotez są odmienne. W pierwszym przypadku bowiem mamy do czynienia z konsultacją określaną w literaturze mianem współuczestnictwa w procesie decyzyjnym (co - deliberazione $)^{38}$. W tym wypadku bowiem autorytet kościelny nie może dokonać zamierzonego działania bez uzyskania zgody wszystkich osób prawnie uprawnionych do partycypacji.

\footnotetext{
${ }^{37}$ J. Arrieta, L'attività consultiva, dz. cyt., s. 139.

${ }^{38}$ Tamże, s. 141.
} 
Nieco inne zasady natomiast zastosowano w odniesieniu do rady, o której stanowi ustawodawca w kan. 127 § 2, n. 2 KPK, gdyż w tej hipotezie spotykamy się z figurą opinii obowiązkowej, jednak niewiążą$\operatorname{cej}^{39}$. Pomimo takiego charakteru, rada o której mowa w analizowanej regulacji jest komponentem integrującym procesu decyzyjnego przełożonego ${ }^{40}$. Autorytet ten bowiem w swym postępowaniu nie może ograniczyć się do poinformowania uprawnionych osób o zamierzonym działaniu. Osoby te przecież są zobowiązane do wyrażenia swych opinii w konkretnej sprawie ${ }^{41}$; przełożony natomiast jest zobligowany do ich oceny, niezależnie od decyzji finalnej, którą podejmie. W ocenie stanu faktycznego w pierwszym rzędzie powinien wziąć on pod uwage dobro wspólnoty Kościoła ${ }^{42}$. Stąd też w analizowanym kanonie występuje zalecenie, aby przełożony nie odstępował od opinii wyrażonej przez osoby, zwłaszcza wtedy gdy są one zgodne, a w szczególności, jeśli nie znajduje on racjonalnych argumentów przemawiających za zajęciem stanowiska odrębnego ${ }^{43}$. Według L.Veli, zadaniem osób partycypujących w decyzji przełożonego jest ukazanie prawdy, nawet wtedy gdy opinia ta nie jest podzielana przez przełożonego. Dlatego też przełożony w podejmowaniu decyzji powinien pójść za sugestiami konsultowanych osób ${ }^{44}$.

\section{The principles of functioning of acts by a superior requiring the consultative cooperation of certain persons (can. 127 \& $\mathrm{CIC}$ )}

The author of the presented article out thorough interpretation of can. 127 § 2 CIC. The analysis he carried out shows that the legislator included in this regulation two hypotheses connected with the necessity for a superior to obtain the consent or counsel of certain persons. In his research the author proved that there different mechanism

${ }^{39}$ Tamże, s. 142.

${ }^{40}$ Tamże.

${ }^{41}$ Tamże, s. 151-152.

${ }^{42}$ Por. E. SARAceni, L'autorità ragionevole. Premesse per uno studio del diritto canonico amministrativo secondo il principio di ragionevolezza, Milano 2004, s. 33.

${ }^{43}$ J. ArrietA, L'attività consultiva, dz. cyt., s. 142-143.

${ }^{44}$ Por. L. Vela, Atto giuridico, w: Nuovo dizionario del diritto canonico, red. C. Corral Slavador, V. De Paolis, G. Ghirlanda, Ciniselo Balsamo 1993, s. 70. 
behind these two hypotheses. In the first, case, consultation in the form of consent is required. Therefore, a superior cannot make any intended acts without obtaining the consent of all the persons legally established as participants in the consultation.

The counsel, on the other hand, functions in a slightly different way because in this hypothesis the opinion is obligatory but non binding. Despite such a nature of the counsel discussed in the analysed regulation, it remains an integrative component of a superior's decision making process. The authority cannot confine himself to in the persons about his intended acts. This is because the persons are obliged to give their opinion on a specific regulation. A superior at the same time is obliged to asses their opinion regardless of his final decision. 